\title{
Defense behavior and tail loss in the endemic lizard Eurolophosaurus nanuzae (Squamata, Tropiduridae) from southeastern Brazil
}

\author{
Conrado A. B. Galdino ${ }^{1}$, Emiliane G. Pereira ${ }^{2}$, Angélica F. Fontes ${ }^{1}$, and Monique Van Sluys ${ }^{1}$ \\ 1 Setor de Ecologia, Instituto de Biologia Roberto Alcântara Gomes, Universidade do Estado do Rio de Janeiro. Rua \\ São Francisco Xavier, 525, 20550-013, Rio de Janeiro, RJ, Brazil. \\ 2 Museu Nacional, Universidade Federal do Rio de Janeiro. Quinta da Boa Vista, 20940-040, Rio de Janeiro, RJ, Brazil. \\ E-mail: CABG galdinoc@terra.com.br.
}

\begin{abstract}
Defense behavior and tail loss in the endemic lizard Eurolophosaurus nanuzae (Squamata, Tropiduridae) from southeastern Brazil. Defense behavior of the endemic tropidurid lizard Eurolophosaurus nanuzae was studied in an area of rocky outcrops at Serra do Cipó, Minas Gerais State, southeastern Brazil. Tail loss aspects of this species were also studied in lizards from three populations (Diamantina, Serra do Cipó, and Serro, Minas Gerais State, Brazil). Lizards relied primarily on crypsis to avoid detection by predators. Secondary defense strategies involved a complex set of behaviors. Mean maximum distance of flight was $1.68 \pm 1.70 \mathrm{~m}$. When captured, individuals attempted to flee, lifted the tail, produced distress calls, discharged the cloacal contents, waived their tails, and bit. Frequency of tail autotomy was $13.2 \%$ (n = 53) in Diamantina, 11.9\% $(n=42)$ in Serra do Cipó, and 4.1\% $(n=49)$ in Serro. Tail autotomy frequency did not differ among the three populations $\left(X^{2}=3.3\right.$, DF $=$ $2, \mathrm{p}=0.19)$. Tail autotomy did not vary between the years of the study $\left(X^{2}=1.32, \mathrm{p}=\right.$ 0.35 ) and did not differ between males and females among the studied populations.
\end{abstract}

Keywords: Squamata, Tropiduridae, Eurolophosaurus nanuzae, defense behavior, tail autotomy, southeastern Brazil.

\section{Introduction}

Lizards are prey for a wide range of predators including fishes (Shepard 2005), snakes (e.g. McKinney and Ballinger 1966, Germano and Brown 2003), birds (e.g. Greene 1988,

Received 14 September 2005.

Accepted 20 July 2006.

Distributed September 2006.
Trejo et al. 2003, França et al. 2004, Kokubum and Zacca 2004, Smith and Engeman 2004), mammals (e.g. Tuttle 1967, López et al. 2003, Wojnwski and Selempo 2005), invertebrates (e.g. Bauer 1990, Glau et al. 2002, Hampton et al. 2004), and other lizards (e.g. Rocha and Vrcibradic 1998, Avila and Morando 2002, Garcia-De-La-Peña et al. 2003, Vargens et al. 2005), thus it is expected that they have a variety of strategies to increase their chances of 
surviving an encounter with a predator (Rocha 1993). Behavioral mechanisms that prevent predation are often linked to foraging mode of lizard species. Active foragers use rapid running as the primary defense behavior when they meet a predator, whereas sedentary foragers rely mainly on crypsis to avoid detection and run only when threatened by a predator (Cooper 1994).

The ability to shed the tail is strongly affected by phylogenetic history of lizards (Zani 1996). Many factors play a role in the measured frequency of tail autotomy in lizards including type of habitat and habits, frequency of intraspecifc aggression, prevalence and type of predators, longevity of individuals, and sample size and composition (Bellairs and Bryant 1985). Tail autotomy is interpreted as an evolved feature that allows escape from predators (Vitt and Ballinger 1982, Arnold 1984). Lizard tails may have important functions such as balancing the body while perched (Ballinger 1973), storing energy in the form of fat, and aiding in locomotion (Vitt and Ballinger 1982). Additionally, lizards with non-autotomized tails tend to occupy dominant status in social hierarchies (Martín and Salvador 1993). Thus, loss of part of the tail may impose costs for lizards such as reduced growth (Niewiarowski et al. 1997) and impaired reproduction (Martín and Salvador 1993).

Lizard tail break frequencies may vary between sexes and among populations. Sex differences may be due to different social roles of males and females in territorial species. In this case males behave more conspicuously than females, becoming more susceptible to a predatory attack (Schoener and Schoener 1980), or they may engage in agonistic conspecific interactions that increase the chances of tail loss. Habitat coverage may account for differences in tail break frequencies among lizard populations. It is expected that lizards inhabiting open habitats are more susceptible to a predator attack then those inhabiting forest habitats, since habitat complexity of close-forested areas may provide additional refuges for lizards (Schoener and Schoener 1980).

The small-sized tropidurid lizard Eurolophosaurus nanuzae occurs at altitudes above 1000 $\mathrm{m}$ in open vegetation typical of rocky field habitats, locally known as "Campos Rupestres" (Rodrigues 1981), along the Espinhaço Mountain Range, in eastern Brazil. This primarily saxicolous lizard reproduces seasonally (Galdino et al. 2003) and feeds mostly on termites and ants (Kiefer 1998). Because species that live in open areas are normally under intense predator pressure (Greene 1988), we hypothesize that $E$. nanuzae may have a wide variety of defensive mechanisms. Our specific goals are to describe the defensive repertoire of $E$. nanuzae and to evaluate intersexual and interpopulational patterns of tail autotomy.

\section{Materials and Methods}

Fieldwork was conducted in three localities along the Espinhaço Mountain Range, in Minas Gerais State, southeastern Brazil: Diamantina (18 $25^{\prime}$ S, 4360' W), Serra do Cipó (19²0’ S,

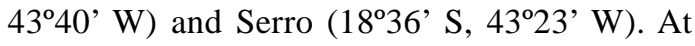
these sites the habitat is dominated by a rocky landscape (“Campos Rupestres”) with the predominance of plant families Eriocaulaceae, Velloziaceae and Melastomataceae (for a detailed description see Giulietti et al. 2000). Behavioral data were obtained for lizards at Serra do Cipó from April to August 2002, and during January and February 2003. Data on tail autotomy were acquired for lizards at the three localities.

We systematically searched for lizards by walking haphazardly through the habitat from 09:00 h to 16:00 h at Serra do Cipó. This period comprises much of the activity time of $E$. nanuzae at Serra do Cipó (CABG unpublished data). When an individual was found we recorded its initial behavior and substrate trying not to disturb it. Then, one of us (CABG) simulated a predator attack upon the individual by suddenly moving in the lizard's direction. 
The same person, wearing similar clothes (following Heatwole 1968, Martín and López 1995, 2000a, 2003), performed all approaches during all observations to avoid confounding effects that might affect the perception of lizards (Burger and Gochfeld 1993). Next we recorded the behaviors exhibited by the lizard using the focal-animal sampling (Altmann 1974). After the attacks, we recorded type of refuge or substrate used by the lizard after flight (Bulova 1994). We also recorded the maximum distance of flight (MDF) for 25 individuals by measuring the distance covered by the lizard from its initial position to its final position (i.e. the place it stopped after being disturbed). All behaviors exhibited during handling were recorded for ten lizards captured by noosing.

Lizards were caught with rubber bands, noose, or by hand in each locality in October 2001 and October 2002. They were euthanized with ether and immediately fixed with formalin $10 \%$. Prior to fixation we measured their snoutvent length (SVL) with a caliper (to the nearest $0.1 \mathrm{~mm}$ ), weighed them with an Acculab Eletronic Balance (to the nearest $0.001 \mathrm{~g}$ ) and sexed them. We examined all lizards for evidence of tail regeneration. To analyze differences in the frequency of tail autotomy among years we used data collected during a mark-recapture study carried out from June 2001 to December 2003. Tail status was recorded only for the first time those lizards were captured. Differences in the proportion of tail-breaks between sexes, among populations, and among years were tested using chi-square tests (Zar 1999).

\section{Results}

Most individuals were initially found motionless on the substrate (rocks) $(94.5 \%$; $=73$ ) or, in the case of juveniles, in grass (5.5\%). The primary defense mechanism observed by $E$. nanuzae was lack of movement enhancing the effects of cryptic coloration and disruptive markings. Eurolophosaurus nanuzae has gray background coloration with dorsolateral black bands and a disruptive mark in the ocular region.

The secondary defense strategies used by $E$. nanuzae at Serra do Cipó involved a complex set of behaviors. The majority of individuals ran towards the vegetation $(40.8 \% ; \mathrm{N}=73$ ), while $29.6 \%$ exploited crevices, $28.2 \%$ ran to other rock when threatened and few used burrows as refuge (1.4\%). After fleeing a certain distance, lizards frequently stopped and remained motionless again. The other behaviors observed were tail waving (one individual) and tail upstanding (three individuals). Mean MDF was $1.68 \pm 1.70 \mathrm{~m}$ (range from 0.15 to $7.50 \mathrm{~m}, \mathrm{~N}=$ 25). For captured individuals the following displays were recorded: flight attempts $(\mathrm{N}=7)$, tail upstand $(\mathrm{N}=4)$, distress calls $(\mathrm{N}=4)$, cloacal discharge $(\mathrm{N}=4)$, tail waving $(\mathrm{N}=3)$, and biting $(\mathrm{N}=2)$.

We collected $163 \mathrm{E}$. nanuzae at the three sites (58 females and 105 males). Twenty-one lizards were not considered in the analysis because of uncertainty in assigning the tail status. The frequencies of tail autotomy were $13.2 \%(\mathrm{~N}=53)$ in Diamantina, $11.9 \%(\mathrm{~N}=42)$ in Serra do Cipó, and $4.1 \%(\mathrm{~N}=49)$ in Serro. Tail autotomy frequency did not differ among the three populations $\left(X^{2}=3.3, \mathrm{DF}=2, \mathrm{p}=0.19\right)$. Tail brake did not differ between sexes in each locality (Diamantina: $X^{2}=119, \mathrm{p}=0.27$; Serra do Cipó: $X^{2}=0.004, \mathrm{p}=0.94$; Serro: $X^{2}=0.94, \mathrm{p}=0.57$ )

During the mark-recapture study we collected 137 lizards of which $10.7 \%$ had broken/regenerated tails. Tail autotomy did not vary between the years of the study $\left(X^{2}=1.32, \mathrm{p}=0.35\right)$.

\section{Discussion}

As was expected for a sit-and-wait forager species, E. nanuzae at Serra do Cipó relied on crypsis as its primary defensive mechanism (e.g. Cooper 1994). Crypsis is an effective mechanism to prevent detection by predators. Because movements disrupt the concealing effect (Greene 1988), cryptic organisms should remain motionless for as much time as possible. 
Similar to many other lizard species, E. nanuzae escape from predators by running and hiding into a refuge (e.g. Greene 1988, Rocha 1993, Bulova 1994, Díaz-Uriarte 1999, Martín and López 1995, 2000a). However, some individuals run to the nearest boulder and rely on crypsis again. Galdino et al. (2003) suggested that one of the selective forces leading to a small and relatively fixed clutch size in E. nanuzae might involve the use of crevices as refuges. However, the majority (68\%) of sampled individuals of $E$. nanuzae did not hide in a crevice when threatened. The use of crevices may pose some costs for a lizard that would increase the chances of being captured in a subsequent predatory attack (see Martín 2001, Vitt et al. 2002). For example, the loss of visual contact with the predator, as well as thermal costs, given that refuges may have lower temperatures than the open substrate (Martín and López 2000b). Thus the use of this kind of refuge may be restricted to occasions when the costs of being preyed upon outweigh costs of using crevices. If this is the case for E. nanuzae, then factors other than the use of crevices might determine relatively low and fixed clutch size in this species. Nevertheless, more studies are needed to evaluate this.

The frequency of tail autotomy of E. nanuzae in the present work is lower than that reported by Van Sluys et al. (2002) for the Serra do Cipó population, where $27.8 \%$ of the individuals had broken/regenerated tails. Tail loss did not differ between sexes, among populations, or among years. It is known that males of territorial species behave more conspicuously than females (they have to scan its territory against intruders and frequently engages in agonistic interactions with intruders that may pose a risk of injury), what increases the chances of injury due to a predator attack or during agonistic conspecific interaction (Schoener and Schoener 1980, Van Sluys et al. 2002). Males and females of $E$. nanuzae seem to defend an area of exclusive use (Galdino and Van Sluys, unpublished data), thus individuals of both sexes tend to be equally susceptible to injury due to intra-specific aggression or to predation pressure (Whiting 2002). It is expected that tail break frequencies differ among populations due to differences in habitat structure (Schoener and Schoener 1980). The evenness of frequencies of tail autotomy among the studied populations of E. nanuzae may be addressed to the fact that the three studied sites are open rock outcrops habitats.

\section{Acknowledgements}

We are grateful to Geraldo W. Fernandes for the permission to work at his property at Serra do Cipó, Tadeu J. Guerra for the logistic support, and IBAMA for the license for collecting the lizards ( $\mathrm{n}^{\circ}$ 037/02-RAN) and for logistic support. We also thank Thais KlaionFerreira, Davor Vrcibradic and Vanderlaine A. Menezes for their help during fieldwork. Davor Vrcibradic also kindly reviewed the manuscript. During this work CABG received a Ph.D. grant from CAPES.

\section{References}

Altmann, J. 1974. Observational study of behavior: sampling methods. Behaviour 49: 227-267.

Arnold, E. N. 1984. Evolutionary aspects of tail shedding in lizards and their relatives. Journal of Natural History 18: 127-169.

Avila. L. J. and M. Morando. 2002. Liolaemus petrophilus (NCN). Saurophagy. Herpetological Review 33: 52.

Ballinger, R. E. 1973. Experimental evidence of the tail as a balance organ in the lizard, Anolis carolinensis. Herpetologica 29: 65-66.

Bauer, A. M. 1990. Geckonid lizards as prey of invertebrates and predators of vertebrates. Herpetological Review 21: 83-87.

Bellairs, A. and S. V. Bryant. 1985. Autotomy and regeneration in reptiles. Pp. 301-410 in C. Gans and F. Billett (eds.), Biology of the Reptilia. New York. John Wiley and Sons.

Bulova, S. J. 1994. Ecological correlates of population and individual variation in antipredator behavior of two species of desert lizards. Copeia 1994: 980-992.

Burger, J. and M. Gochfeld. 1993. The importance of the 
human face in risk perception by black iguanas, Ctenosaura similis. Journal of Herpetology 27: 426430 .

Cooper, W. E., Jr. 1994. Prey chemical discrimination, foraging mode, and phylogeny. Pp. 95-116 in L. J. Vitt and E. R. Pianka (eds.), Lizard Ecology. New Jersey. Princeton University Press.

Díaz-Uriarte, R. 1999. Anti-predator behaviour changes following an agressive encounter in the lizard Tropidurus hispidus. Proceedings of the Royal Society of London B Biological Sciences 266: 2457-2464.

França, F. G. R., V. S. Braz and S. F. Balbino. 2004. Briba brasiliana (Lagartixa). Predation. Herpetological Review 35: 386-387.

Galdino, C. A. B., V. B. Assis, M. C. Kiefer, and M. Van Sluys. 2003. Reproduction and fat body cycle of Eurolophosaurus nanuzae (Sauria: Tropiduridae) from a seasonal montane habitat of southeastern Brazil. Journal of Herpetology 4: 687-694.

Garcia-De-La-Peña, C., G. G. Castañeda, D. Lazcano, and A. Jaime-Rosales. 2003. Uma exsul (Fringe-Toed Sand Lizard). Predation. Herpetological Review 34: 370.

Germano, D. J. and J. Brown. 2003. Gambelia sila. (BluntNosed Leopard Lizard). Predation. Herpetological Review 34: 143-144.

Giulietti, A. M., R. M. Harley, L. P. Queiroz, M. G. L. Wanderley, and J. R. Pirani. 2000. Caracterização e endemismos nos campos rupestres da cadeia do espinhaço. Pp. 311-319 in T. B. Cavalcanti and B. M. T. Walter (orgs.), Tópicos Atuais em Botânica: Palestras convidadas do $51^{\circ}$ Congresso Nacional de Botânica. Brasília. Embrapa Recursos Genéticos e Biotecnologia / Sociedade Botânica do Brasil.

Glau, F., M. Vences and W. R. Lourenço. 2002. Geckolepis maculata (Spotted Fishscale Gecko). Predation. Herpetological Review 32: 135.

Greene, H. W. 1988. Antipredator mechanisms in reptiles. Pp. 1-152 in C. Gans and R. B. Huey (eds.), Biology of the Reptilia. Vol. 16. New York. John Wiley and Sons.

Hampton, P. M., C. D. Foster and J. B. Towey. 2004. Scincella lateralis (Ground Skink). Predation. Herpetological Review 35: 269-270.

Heatwole, H. 1968. Relationship of escape behavior and camouflage in anoline lizards. Copeia 1968: 109-113.

Kiefer, M. C. 1998. Dieta, modo de forrageamento e uso de microhábitat em duas espécies simpátricas de Tropidurus (Sauria, Tropiduridae) na Serra do Cipó, Minas Gerais. Unpublished M.Sc. Dissertation. Universidade Estadual Paulista, Brazil.

Kokubum, M. C. and W. Zacca. 2004. Tropidurus torquatus (Calango). Predation. Herpetological Review 35: 270-271.
López, P., J. J. Juque-Lorena and J. Martín. 2003. Lacerta monticola (Iberian Rock Lizard). Predation. Herpetological Review 34: 245.

Martín, J. 2001. When hiding from predators is costly: Optimization of refuge use in lizards. Etología 9: 913.

Martín, J. and P. López. 1995. Influence of habitat structure on the escape tatics of the lizard Psammodromus algirus. Canadian Journal of Zoology 73: 129-132.

Martín, J. and P. López. 2000a. Fleeing to unsafe refuges: effects of conspicuousness and refuge safety on the escape decisions of the lizard Psammodromus algirus. Canadian Journal of Zoology 78: 265-270.

Martín, J. and P. López. 2000b. Costs of refuge use affect escape decisions of Iberian rock lizards Lacerta monticola. Ethology 106: 483-492.

Martín, J. and P. López. 2003. Changes in the escape responses of the lizard Acanthodactilus erythrurus under persistent predatory attacks. Copeia 2003: 408413.

Martín, J. and A. Salvador. 1993. Tail loss reduces mating success in the Iberian rock-lizard, Lacerta monticola. Behavioral Ecology and Sociobiology 32: 185-189.

McKinney, C. O. and R. E. Ballinger. 1966. Snakes predators of lizards in western Texas. Southwestern Naturalist 11: 410-412.

Niewiarowski, P. H., J. D. Congdon, A. E. Dunham, L. J. Vitt, and D. W. Tinkle. 1997. Tales of Uta tails: Effects of tail autotomy on subsequent survival and growth of free-ranging hatchling Uta stansburiana. Canadian Journal of Zoology 75: 542-548.

Rocha, C. F. D. 1993. The set of defence mechanisms in a tropical sand lizard (Liolaemus lutzae) of southeastern Brazil. Ciência e Cultura 45: 116-122.

Rocha, C. F. D. and D. Vrcibradic. 1998. Reptiles as predators of vertebrates and as preys in a restinga habitat of southeastern Brazil. Ciência e Cultura 50: 364-368.

Rodrigues, M. T. 1981. Uma nova espécie de Tropidurus do sudeste do Brasil (Sauria, Iguanidae). Papéis Avulsos de Zoologia, São Paulo 34: 145-149.

Shepard, D. B. 2005. Eumeces fasciatus (Five-Lined Skink). Predation. Herpetological Review 36: 177.

Schoener, T. W. and A. Schoener. 1980. Ecological and demographic correlates of injury rates in some Bahamian Anolis lizards. Copeia 1980: 839-850.

Smith H. T. and R. M. Engeman. 2004. Leiocephalus carinatus armouri (Northern Curlytailed lizard). Predation. Herpetological Review 35: 169-170.

Trejo, A., S. Seijas, and M. Sahores. 2003. Liolaemus lineomaculatus (NCN). Predation. Herpetological Review 34: 145. 
Tuttle, M. D. 1967. Predation by Chrotopterus auritus on geckos. Journal of Mammalogy 48: 319.

Van Sluys, M., D. Vrcibradic and C. F. D. Rocha. 2002. Tail loss in the syntopic lizard Tropidurus itambere (Tropiduridae) and Mabuya frenata (Scincidae) in southeastern Brazil. Studies on Neotropical Fauna and Environment 37: 227-231.

Vargens, M. M. F., A. B. D’Angiolella and E. J. Dias. 2005. Coleodactylus meridionalis (NCN). Predation. Herpetological Review 36: 173-174.

Vitt, L. J. and R. E. Ballinger. 1982. The adaptative significance of a complex caudal adaptation in the tropical gekkonid lizard Lygodactylus klugei. Canadian Journal of Zoology 60: 2582-2587.
Vitt, L. J., W. E. Cooper, Jr., A. Perera, and V. PerézMellado. 2002. Escaping predators on vertical surfaces: Lacerta perspicillata in Roman quarries of Líthaca. Canadian Journal of Zoology 80: 1803-1809.

Whiting, M. J. 2002. Field experiments on intersexual differences in predation risk and escape behaviour in the lizard Platysaurus broadleyi. Amphibia-Reptilia 23: $119-124$.

Wojnowski, D. and E. Selempo. 2005. Hemidactylus mabouia (Tropical House Gecko). Predation. Herpetological Review 36: 178-179.

Zani, P. A. 1996. Patterns of caudal-autotomy evolution in lizards. Journal of Zoology (London) 240: 201-220.

Zar, J. 1999. Biostatistical Analysis. New Jersey. Prentice Hall, Englewood Cliffs. 